\title{
Role of Adipose-Derived Mesenchymal Stem Cells in the Regeneration of Cardiac Tissue and Improvement of Cardiac Function: a Narrative Review
}

\author{
Mnasour Bahardoust 1,2 (D), Zahra Bagheri-Hosseinabadi ${ }^{3, *(D)}$ \\ 1 Department of Epidemiology, School of Public Health, Iran University of Medical Sciences, Tehran, Iran; \\ mansourbahari93@gmail.com, (M.B.); \\ 2 Colorectal Research Center, Iran University of Medical Sciences, Tehran, Iran; mansourbahari93@gmail.com, (M.B.); \\ 3 Department of Clinical Biochemistry, Faculty of Medicine, Rafsanjan University of Medical Sciences, Rafsanjan, Iran, \\ baghery.zahra@yahoo.com, (Z.B.H.); \\ * Correspondence: baghery.zahra@yahoo.com;
}

Scopus Author ID 57197848794

Received: 1.07.2020; Revised: 25.07.2020; Accepted: 26.07.2020; Published: 28.07.2020

Abstract: Recent efforts have made in order to novel therapeutic approaches to reduce the heavy cardiovascular burden. The use of cell therapy and applying stem cell-based therapies has received much attention; of particular interest are adipose-derived mesenchymal stem cells (ADSCs). The present review aimed to review the studies which examined and researched various aspects of ADSCs to improve cardiac function. A comprehensive review of all articles assessed and discussed the application of ADSCs in the improvement of cardiac tissue renewing and cardiomyocytes regeneration was planned and conducted by the two reviewers. The initial literature search revealed a total of 153 articles that, of those, 34 were considered eligible. From the perspective of heart tissue regeneration, the inductive role of ADSCs in sensing mechanical stimulation and produce collagen and elastin scaffolds, vascularizing cardiac tissue, and exosomes (vesicles derived from ADSCs) in ADSCsmediated myocardial protection has indicated. In the process of ADSCs differentiation to cardiomyocyte- like cells, the role of various targeted pathways have been identified that can be influenced by different elements such as TGF-beta1, phorbol myristate acetate, Angiotensin II, Rhoassociated kinases, 5-Azaytidine, Sodium valproate, fibrin scaffold and trichostatin A have been highlighted. In the final, from a therapeutic point of view, the effectiveness of ADMSCs differentiation to cardiomyocytes as improving left ventricular functional state has been discussed. Summarizing the studies confirms a significant improvement in cardiac function following direct application of ADSCs or their transformation to cardiomyocytes by stimulating or inhibiting various cellular pathways leading reducing oxidative stress and inflammatory bed, reducing cardiomyocyte apoptosis, attenuating cardiac fibrosis, reducing the infiltration of immune cells and collagen deposition, and enhancing angiogenesis.

Keywords: Mesenchymal stem cells; adipose tissue; cardiology; cell differentiation.

(C) 2020 by the authors. This article is an open-access article distributed under the terms and conditions of the Creative Commons Attribution (CC BY) license (https://creativecommons.org/licenses/by/4.0/).

\section{Introduction}

Improving live expectancy, as well as reducing disability, is the main goal for clinicians dealing with chronic life-threatening or acute debilitating diseases. Conventional treatments fail in many cases and, therefore, do not succeed in reducing the heavy burden of the diseases $[1,2]$. In this regard, cardiovascular disease, as the most common cause of morbidity and disability in the world, is at the forefront of diseases that, despite the many successes in their 
treatment, continue to fall victim [3]. Even with unfavorable life patterns and sedentary lifestyles, we are faced with an upward trend in these diseases and their adverse consequences [4]. Therefore, recent efforts have made in order to novel therapeutic approaches to reduce the heavy cardiovascular burden. Accordingly, the use of cell therapy and applying stem cell-based therapies has received much attention [5,6]. Of particular interest are mesenchymal stem cells (MSCs) [7,8]. In this regard, different therapeutic approaches have been described in the literature in the use of these types of cells for treatment. In initial experiences, MSCs were initially inserted in the bone marrow with the capacity to regenerate bone and to create the niche for hematopoietic stem cells, known as bone-marrow mesenchymal stem cells $[9,10]$. In the next attempts, the extraction of such cells from other distinct and specific tissues of the body, such as adipose tissue, skin, musculoskeletal tissues, lungs, and even placenta has been possible [11]. The main feature of these cells is their high potential in differentiating to other specialized tissues, especially connective tissues, and the same feature is used to renew damaged tissues and organs [12]. In this regard, different mechanisms have been described for MSCs - based therapy. First, MSCs can differentiate into the targeted cell types and contribute to regenerate the injured tissue[13]. Second, due to potential secretory role, MSCs can secrete various growth factors and cytokines, facilitating cell proliferation, inducing vascularization, and angiogenesis [14]. Third, MSCs have immunomodulatory role leading control and inhibition of inflammation processes leading tissue injury [15]. Although both adipose-derived mesenchymal stem cells (ADSCs) and bone marrow mesenchymal stem cells (BM-MSCs) are now commonly used for regenerating damaged tissues, ADSCs have more potential advantages. First, ADSCs are more accessible commonly from subcutaneous fat tissue or supra- and infra-patellar fat pads and by lipoaspirates or adipose tissue biopsy, leading to a lower burden of morbidity on patients as well as higher satisfaction [16]. Second, it seems that ADSCs have more immune properties leading to lower risk for rejection and also higher proliferation rate as compared to BM-MSCs [17]. To access ADSCs from fat tissue, following enzymatic digestion process, a stromal vascular fraction can be extracted from the adipose tissue consisting a mixture of regenerative cell types and various immune cells, including preadipocytes, fibroblasts, vascular smooth muscle cells, endothelial cells, resident monocyte, and lymphocytes, but ADSCs make up about $30 \%$ of the total mixture extracted $[18,19]$. ADSCs are naturally located in the capillary and perivascular adventitia of large blood vessels within adipose tissues and are thought to be derived from pericytes [20]. The main potential of ADSCs is to proliferate to stem cells reservoir in the undifferentiated state during life and also to give rise to different types of both mesenchymal cell lines (such as fibrocytes, chondrocytes, and osteocytes) and also non- mesenchymal cell lines (such as hepatocytes, neuronal, and cardiomyocytes) [21,22]. Based on this ability to regenerate cardiomyocytes, the use of these cells has been widely proposed to regenerate myocardial tissue. Moreover, due to immunomodulation, meaning, and anti-inflammatory properties of ADSCs, the induction and promotion of anti-cardiac ischemic-related processes such as new angiogenesis, tissue remodeling, and cell apoptosis are possible. The present review aimed to review the studies which examined and researched various aspects of ADSCs to improve cardiac function.

\section{Materials and Methods}

A comprehensive review of all articles assessed and discussed the application of ADSCs in the improvement of cardiac tissue renewing and cardiomyocytes regeneration was planned. The primary search was conducted according to the main keywords including "heart", 
"cardiac function", "myocardium", "cardiomyocyte", and "adipose-derived mesenchymal stem cell" using different databases including PubMed, MEDLINE, SCOPUS, Google Scholar, and Cochrane Library. The searching was conducted by the two reviewers, which blinded each other, and finally, their evaluation results were summarized. Eligibility criteria included English-language papers with full-text availability, including both animal and human models, in vivo and in vitro assessments. Exclusion criteria consisted of the clinical or experimental the predominant pathologies except for the cardiovascular system, multiple publications of a single trial, case studies, or reviews. The initial literature search revealed a total of 153 articles that of those, 34 were considered eligible and included in this review (Table 1). Data from all papers deemed relevant was extracted then independently reviewed by investigators.

Table 1. Summary of the studies.

\begin{tabular}{|c|c|c|c|c|}
\hline Author, year & Type of study & Target cells/disease & Main issue & Main results \\
\hline $\begin{array}{l}\text { Bagheri, } 2020 \\
\text { [34] }\end{array}$ & Exp./in vitro & $\begin{array}{ll}\text { Differentiation } & \text { of } \\
\text { ADMSCs } & \text { to } \\
\text { cardiomyocyte } & \\
\end{array}$ & $\begin{array}{l}\text { Cell } \\
\text { differentiation }\end{array}$ & $\begin{array}{l}\text { 5-Azaytidine can induce hADSCs to } \\
\text { differentiate into cardiomyocytes. }\end{array}$ \\
\hline $\begin{array}{l}\text { Bao, } 2020 \\
{[27]}\end{array}$ & Exp./in vitro & Cardiac transplantation & $\begin{array}{l}\text { Tissue } \\
\text { regeneration }\end{array}$ & $\begin{array}{l}\text { Toll-Like Receptor } 3 \text { activator } \\
\text { preconditioning enhances modulatory } \\
\text { function of ADMSCs in heterotopic } \\
\text { heart transplantation }\end{array}$ \\
\hline $\begin{array}{l}\text { Zhang, } 2020 \\
{[51]}\end{array}$ & $\begin{array}{l}\text { Exp./animal } \\
\text { model }\end{array}$ & $\begin{array}{l}\text { Acute myocardial } \\
\text { infarction }\end{array}$ & Therapy & $\begin{array}{l}\text { ADMSCs can promote the resolution } \\
\text { of cardiac inflammation after } \\
\text { ischemia-reperfusion via enhancing } \\
\text { efferocytosis of neutrophils }\end{array}$ \\
\hline $\begin{array}{l}\text { Gao, } 2020 \\
{[52]}\end{array}$ & $\begin{array}{l}\text { Exp./animal } \\
\text { model }\end{array}$ & $\begin{array}{ll}\text { Acute } & \text { myocardial } \\
\text { infarction } & \end{array}$ & Therapy & $\begin{array}{l}\text { Cardio-renal exosomes deliver miR- } \\
1956 \text { and activate paracrine } \\
\text { proangiogenic VEGF signaling in } \\
\text { ADMSCs used for cardiac } \\
\begin{array}{l}\text { regeneration after myocardial } \\
\text { infarction }\end{array}\end{array}$ \\
\hline $\begin{array}{l}\text { Qayyum, } 2019 \\
\text { [53] }\end{array}$ & $\begin{array}{l}\text { Human clinical } \\
\text { trial }\end{array}$ & $\begin{array}{l}\text { Chronic Ischemic } \\
\text { Heart Disease }\end{array}$ & Therapy & $\begin{array}{l}\text { ADMSCs therapy could not improve } \\
\text { myocardial perfusion, functional } \\
\text { parameters or amount of scar tissue }\end{array}$ \\
\hline $\begin{array}{l}\text { Chai, } 2019 \\
{[54]}\end{array}$ & $\begin{array}{l}\text { Exp./animal } \\
\text { model }\end{array}$ & $\begin{array}{l}\text { Ischemia-reperfusion } \\
\text { injury }\end{array}$ & Therapy & $\begin{array}{l}\text { Combined cold water-exosome } \\
\text { therapy improves myocardial function } \\
\text { and reduces oxidative and } \\
\text { inflammatory effects following } \\
\text { ischemia-reperfusion injury }\end{array}$ \\
\hline $\begin{array}{l}\text { Qiao, } 2019 \\
{[55]}\end{array}$ & $\begin{array}{l}\text { Exp./animal } \\
\text { model }\end{array}$ & $\begin{array}{l}\text { Acute myocardial } \\
\text { infarction }\end{array}$ & Therapy & $\begin{array}{l}\text { Combining ADMSCs and myocardial } \\
\text { decellularized extracellular matrix has } \\
\text { synergistic effects on cardiac repair }\end{array}$ \\
\hline $\begin{array}{l}\text { Deng, } 2019 \\
{[26]}\end{array}$ & Exp./in vitro & $\begin{array}{l}\text { Acute myocardial } \\
\text { infarction }\end{array}$ & $\begin{array}{l}\text { Tissue } \\
\text { regeneration }\end{array}$ & $\begin{array}{l}\text { Exosomes from } \\
\text { ameliorate cardiac damage }\end{array} \begin{array}{r}\text { ADSCr } \\
\text { after } \\
\text { myocardial infarction by activating } \\
\begin{array}{l}\text { S1P/SK1/S1PR1 signaling and } \\
\text { promoting macrophage } \\
\text { polarization }\end{array}\end{array}$ \\
\hline $\begin{array}{l}\text { Pan, } 2019 \\
{[25]}\end{array}$ & Exp./in vitro & $\begin{array}{l}\text { Acute myocardial } \\
\text { infarction }\end{array}$ & $\begin{array}{l}\text { Tissue } \\
\text { regeneration }\end{array}$ & $\begin{array}{l}\text { Exosomes derived from miR-146a- } \\
\text { modified ADMSCs attenuate } \\
\text { myocardial damage via down- } \\
\text { regulation of early growth response } \\
\text { factor 1 (EGR1) }\end{array}$ \\
\hline $\begin{array}{l}\text { Sheu, } 2019 \\
{[56]}\end{array}$ & $\begin{array}{l}\text { Exp./animal } \\
\text { model }\end{array}$ & $\begin{array}{l}\text { Acute myocardial } \\
\text { infarction }\end{array}$ & Therapy & $\begin{array}{l}\text { Transplantation of ADMSCs resulted } \\
\text { in smaller infarcts and } \\
\text { rescued cardiac function by improving } \\
\text { left ventricular function and reducing } \\
\text { inflammation and apoptosis }\end{array}$ \\
\hline Najafipour, 2019 & Exp./in vitro & $\begin{array}{l}\text { Differentiation } \\
\text { ADMSCs } \\
\text { cardiomyocyte }\end{array}$ & $\begin{array}{l}\text { Cell } \\
\text { differentiation }\end{array}$ & $\begin{array}{l}\text { Sodium valproate can } \\
\text { cardiomyogenesis in ADMSCs }\end{array}$ \\
\hline $\begin{array}{l}\text { Zhang, } 2018 \\
\text { [57] }\end{array}$ & Exp./in vitro & $\begin{array}{l}\text { Differentiation } \\
\text { ADMSCs } \\
\text { cardiomyocyte }\end{array}$ & $\begin{array}{l}\text { Cell } \\
\text { differentiation }\end{array}$ & $\begin{array}{l}\text { ADMSCs differentiation to } \\
\text { cardiomyocyte can be enhanced by } \\
\text { TGF- } \beta 1 \text { effect on increased }\end{array}$ \\
\hline
\end{tabular}




\begin{tabular}{|c|c|c|c|c|}
\hline Author, year & Type of study & Target cells/disease & Main issue & Main results \\
\hline & & & & $\begin{array}{l}\text { phosphorylation of the Smad signaling } \\
\text { pathway }\end{array}$ \\
\hline $\begin{array}{l}\text { Abd Emami, } 2018 \\
\text { [44] }\end{array}$ & $\begin{array}{l}\text { Exp./animal } \\
\text { model }\end{array}$ & $\begin{array}{l}\text { Acute myocardial } \\
\text { infarction }\end{array}$ & Therapy & $\begin{array}{l}\text { Scar size reduction and recovery of } \\
\text { left ventricular function after } \\
\text { transplantation of ADMSCs }\end{array}$ \\
\hline $\begin{array}{l}\text { Mori, } 2018 \\
{[45]}\end{array}$ & $\begin{array}{l}\text { Exp./animal } \\
\text { model }\end{array}$ & $\begin{array}{l}\text { Ischemic } \\
\text { Cardiomyopathy }\end{array}$ & Therapy & $\begin{array}{l}\text { Improving systolic and diastolic } \\
\text { function by implantation of allogeneic } \\
\text { ADMSCs in cardiac tissue }\end{array}$ \\
\hline $\begin{array}{l}\text { Morrissett, } 2018 \\
{[24]}\end{array}$ & Exp./in vitro & Vascular tissue repair & $\begin{array}{l}\text { Tissue } \\
\text { regeneration }\end{array}$ & $\begin{array}{l}\text { Combining ADMSCs with ventricular } \\
\text { cardiomyocytes facilitate the } \\
\text { formation } \\
\text { vascularized cardiac tissues }\end{array}$ \\
\hline Bagheri, 2018 & Exp./in vitro & $\begin{array}{ll}\text { Differentiation } & \text { of } \\
\text { ADMSCs } & \text { to } \\
\text { cardiomyocyte } & \end{array}$ & $\begin{array}{l}\text { Cell } \\
\text { differentiation }\end{array}$ & $\begin{array}{l}\text { Fibrin scaffold with a compressive } \\
\text { stress of } 107.74 \mathrm{kPa} \text { allows a higher } \\
\text { differentiation of ADMSCs into } \\
\text { cardiomyocyte-like cells treated with } \\
50 \mu \mathrm{M} \text { 5-Aza. }\end{array}$ \\
\hline Bagheri, 2018 & Exp./in vitro & $\begin{array}{ll}\text { Differentiation } & \text { of } \\
\text { ADMSCs } & \text { to } \\
\text { cardiomyocyte } & \end{array}$ & $\begin{array}{l}\text { Cell } \\
\text { differentiation }\end{array}$ & $\begin{array}{lc}\text { The } & \text { combination } \\
\text { of fibrin scaffold and } & \text { trichostatin A } \\
\text { for differentiation of } & \text { ADMSCs } \\
\text { into cardiomyocyte-like cells }\end{array}$ \\
\hline $\begin{array}{l}\text { Fikry, } 2017 \\
{[46]}\end{array}$ & $\begin{array}{l}\text { Exp./animal } \\
\text { model }\end{array}$ & $\begin{array}{ll}\begin{array}{l}\text { Acute } \\
\text { infarction }\end{array} & \text { myocardial } \\
\end{array}$ & Therapy & $\begin{array}{l}\text { ADMSCs can attenuate cardiac } \\
\text { fibrosis induced by methotrexate }\end{array}$ \\
\hline $\begin{array}{l}\text { Cui, } 2017 \\
{[58]}\end{array}$ & $\begin{array}{l}\text { Exp./animal } \\
\text { model }\end{array}$ & $\begin{array}{l}\text { Ischemia-reperfusion } \\
\text { injury }\end{array}$ & Therapy & $\begin{array}{l}\text { Exosomes ADMSCs protect the } \\
\text { myocardium against Injury through } \\
\text { Wnt/ } \beta \text {-Catenin signaling pathway }\end{array}$ \\
\hline $\begin{array}{l}\text { Wystrychowski, } \\
2016[33]\end{array}$ & Exp./in vitro & $\begin{array}{ll}\begin{array}{l}\text { Differentiation } \\
\text { ADMSCs }\end{array} & \text { of } \\
\text { cardiomyocyte } & \text { to } \\
\end{array}$ & $\begin{array}{l}\text { Cell } \\
\text { differentiation }\end{array}$ & $\begin{array}{l}\text { Epicardial ADMSCs has higher } \\
\text { cardiomyogenic potential as compared } \\
\text { with pericardial and omental }\end{array}$ \\
\hline $\begin{array}{l}\text { Han, } 2016 \\
{[50]}\end{array}$ & $\begin{array}{l}\text { Exp./animal } \\
\text { model }\end{array}$ & $\begin{array}{l}\text { Acute myocardial } \\
\text { infarction }\end{array}$ & Therapy & $\begin{array}{l}\text { Melatonin facilitates ADMSCs to } \\
\text { repair the murine infarcted heart via } \\
\text { the SIRT1 signaling pathway }\end{array}$ \\
\hline $\begin{array}{l}\text { Ammar, } 2015 \\
\text { [49] }\end{array}$ & $\begin{array}{l}\text { Exp./animal } \\
\text { model }\end{array}$ & $\begin{array}{l}\text { Acute myocardial } \\
\text { infarction }\end{array}$ & Therapy & $\begin{array}{l}\text { ADMSCs is effective in mitigating } \\
\text { cardiac damage by promoting } \\
\text { angiogenesis, decreasing the } \\
\text { infiltration of immune cells and } \\
\text { collagen deposition }\end{array}$ \\
\hline $\begin{array}{l}\text { Liu, } 2015 \\
{[48]}\end{array}$ & $\begin{array}{l}\text { Exp./animal } \\
\text { model }\end{array}$ & $\begin{array}{ll}\text { Acute } & \text { myocardial } \\
\text { infarction } & \end{array}$ & Therapy & $\begin{array}{l}\text { Priming of ADMSCs with curcumin } \\
\text { improve tolerance to oxidative stress } \\
\text { injury and resulted in enhancement of } \\
\text { therapeutic potential of ADMSCs for } \\
\text { myocardial repair. }\end{array}$ \\
\hline $\begin{array}{l}\text { Han, } 2015 \\
{[47]}\end{array}$ & $\begin{array}{l}\text { Exp./animal } \\
\text { model }\end{array}$ & $\begin{array}{ll}\text { Acute } & \text { myocardial } \\
\text { infarction }\end{array}$ & Therapy & $\begin{array}{lr}\text { Intramyocardial injection of } & \text { ADMSCs } \\
\text { combining with ghrelin } & \text { inhibits } \\
\text { cardiomyocyte apoptosis, } & \text { reduced } \\
\text { fibrosis, } & \text { and } \\
\text { improved cardiac function } & \text { through } \\
\text { PI3K/Akt pathway } & \end{array}$ \\
\hline $\begin{array}{l}\text { Zhao, } 2014 \\
{[32]}\end{array}$ & Exp./in vitro & $\begin{array}{ll}\begin{array}{l}\text { Differentiation } \\
\text { ADMSCs }\end{array} & \text { of } \\
\text { cardiomyocyte } & \text { to } \\
\end{array}$ & $\begin{array}{l}\text { Cell } \\
\text { differentiation }\end{array}$ & $\begin{array}{l}\text { Rho-associated protein kinases } \\
\text { enhance ADMSCs differentiation into } \\
\text { cardiomyocytes }\end{array}$ \\
\hline $\begin{array}{l}\mathrm{Li}, 2014 \\
{[43]}\end{array}$ & $\begin{array}{l}\text { Exp./animal } \\
\text { model }\end{array}$ & $\begin{array}{l}\text { Dilated } \\
\text { cardiomyopathy }\end{array}$ & Therapy & $\begin{array}{l}\text { Improving left ventricular function } \\
\text { and ventricular dilatation remodeling } \\
\text { by differentiating ADMSCs to } \\
\text { myocardial cells }\end{array}$ \\
\hline $\begin{array}{l}\text { Preda, } 2014 \\
{[42]}\end{array}$ & $\begin{array}{l}\text { Exp./animal } \\
\text { model }\end{array}$ & $\begin{array}{l}\text { Ischemia-reperfusion } \\
\text { injury }\end{array}$ & Therapy & $\begin{array}{l}\text { Transplantation of ADMSCs resulted } \\
\text { in smaller infarcts and } \\
\text { improved cardiac function }\end{array}$ \\
\hline $\begin{array}{l}\text { Song, } 2013 \\
{[31]}\end{array}$ & Exp./in vitro & $\begin{array}{ll}\begin{array}{l}\text { Differentiation } \\
\text { ADMSCs }\end{array} & \text { of } \\
\text { cardiomyocyte } & \text { to } \\
\end{array}$ & $\begin{array}{l}\text { Cell } \\
\text { differentiation }\end{array}$ & $\begin{array}{l}\text { Angiotensin II can induce ADSCs into } \\
\text { cardiomyocyte-like cells }\end{array}$ \\
\hline $\begin{array}{l}\mathrm{Li}, 2013 \\
{[30]}\end{array}$ & Exp./in vitro & CD73+ ADMSCs & $\begin{array}{l}\text { Cell } \\
\text { differentiation }\end{array}$ & $\begin{array}{l}\text { High capacity of CD73+ ADMSCs } \\
\text { capacity for differentiation into } \\
\text { cardiomyocytes }\end{array}$ \\
\hline $\begin{array}{l}\text { Zhang, } 2013 \\
\text { [41] }\end{array}$ & $\begin{array}{l}\text { Exp./animal } \\
\text { model }\end{array}$ & $\begin{array}{l}\text { Acute myocardial } \\
\text { infarction }\end{array}$ & Therapy & $\begin{array}{l}\text { Rosuvastatin enhances the therapeutic } \\
\text { efficacy of ADSCs for MI via } \\
\text { PI3K/Akt and MEK/ERK pathways }\end{array}$ \\
\hline
\end{tabular}




\begin{tabular}{|c|c|c|c|c|}
\hline Author, year & Type of study & Target cells/disease & Main issue & Main results \\
\hline $\begin{array}{l}\text { Chang, } 2012 \\
\text { [29] }\end{array}$ & Exp./in vitro & $\begin{array}{ll}\text { Differentiation } & \text { of } \\
\text { ADMSCs } & \text { to } \\
\text { cardiomyocyte } & \end{array}$ & $\begin{array}{l}\text { Cell } \\
\text { differentiation }\end{array}$ & $\begin{array}{lr}\text { Phorbol myristate } & \text { acetate } \\
\text { differentiates } & \text { ADMSCs into } \\
\text { cardiogenic cells } & \end{array}$ \\
\hline $\begin{array}{l}\text { Bagno, } 2012 \\
{[40]}\end{array}$ & $\begin{array}{l}\text { Exp./animal } \\
\text { model }\end{array}$ & $\begin{array}{l}\text { Acute myocardial } \\
\text { infarction }\end{array}$ & Therapy & $\begin{array}{l}\text { Improving left ventricular function by } \\
\text { administering ADMSCs directly to } \\
\text { the myocardium }\end{array}$ \\
\hline $\begin{array}{l}\text { Cai , } 2011 \\
{[39]}\end{array}$ & $\begin{array}{l}\text { Exp./animal } \\
\text { model }\end{array}$ & $\begin{array}{l}\text { Acute myocardial } \\
\text { infarction }\end{array}$ & Therapy & \begin{tabular}{lr} 
Combining & Atorvastatin \\
with ADMSCs & \multicolumn{2}{c}{ improve } \\
more cardiac function after \\
myocardial infarction
\end{tabular} \\
\hline $\begin{array}{l}\text { Colazzo, } 2011 \\
{[23]}\end{array}$ & Exp./in vitro & $\begin{array}{l}\text { Heart valve tissue } \\
\text { repair }\end{array}$ & $\begin{array}{l}\text { Tissue } \\
\text { regeneration }\end{array}$ & $\begin{array}{l}\text { ADSCs sense mechanical stimulation } \\
\text { and produce collagen and elastin, } \\
\text { improving heart valve tissue }\end{array}$ \\
\hline $\begin{array}{l}\text { Lin, } 2010 \\
{[38]}\end{array}$ & $\begin{array}{l}\text { Exp./animal } \\
\text { model }\end{array}$ & $\begin{array}{l}\text { Dilated } \\
\text { cardiomyopathy }\end{array}$ & Therapy & $\begin{array}{l}\text { Combining sildenafil and ADMSCs } \\
\text { more improve left ventricular function } \\
\text { and angiogenesis }\end{array}$ \\
\hline $\begin{array}{l}\text { Gwak, } 2009 \\
\text { [28] }\end{array}$ & Exp./in vitro & $\begin{array}{l}\text { Differentiation } \\
\text { ADMSCs } \\
\text { cardiomyocyte }\end{array}$ & $\begin{array}{l}\text { Cell } \\
\text { differentiation }\end{array}$ & $\begin{array}{l}\text { TGF-beta1 can induce ADMSCs } \\
\text { cardiomyogenic differentiation }\end{array}$ \\
\hline
\end{tabular}

\section{Results and Discussion}

The studies reviewed with the goal of assessing the role of ADSCs in the improvement of cardiac function can be categorized into three subgroups according to the study design and target issue as 1) experimental in-vitro studies with the focus on the role of ADSCs in heart tissue regeneration; 2) experimental in-vitro studies with the aim of assessing the pathways and mediators for the transformation of ADSCs to specific heart cells; and 3) experimental animal modeling study (only one study included human model) assessing the therapeutic efficacy of ADSCs in a clinical setting. In this regard, our review focuses on the details of each subcategory separately.

\subsection{ADSCs and cardiac tissue regeneration.}

The ability of ADSCs in tissue regeneration has been primarily proposed by Colazzo et al. in 2011 [23]. They showed that ADSCs could sense mechanical stimulation and produce collagen and elastin, leading to improving heart valve tissue. This process was mediated by the upregulation of COL3A1 gene followed by producing collagen and elastin cross-linking and also uniformly populated collagen scaffolds shortly after ADSCs induction. In the next effort, as shown by Morrissett et al. in 2018 [24], Combining ADMSCs with ventricular cardiomyocytes could facilitate the formation of vascularized cardiac tissues, and thus the application of ADSCs led to promote functional vascular tissue engineering for cardiac regenerative goals. Since 2019, the critical role of exosomes for cardiac tissue regeneration was highlighted. In this regard, the obtained evidence by Pen et al. in 2019 [25]. They emphasized that exosomes (30-100 nm small membrane vesicles derived from ADSCs) could play a crucial role in ADSCs-mediated myocardial protection. In their study, it was demonstrated that some miRNAs (such as miR-146a) could promote exosome-mediated cardioprotective effect, and therefore, the link between novel miRNAs and exosomes derived from ADSCs in cardiac tissue regeneration has been explained. In another study by Deng et al. [26]. And in parallel to the previous observation, it was shown that exosomes derived from ADMSCs could ameliorate cardiac damage after myocardial infarction by activating S1P/SK1/S1PR1 signaling and promoting macrophage M2 polarization. In recent studies, the regenerative role of ADSCs as a cardioprotective element, even following cardiac transplantation, has also been revealed. In a recent study by Bao et al. in 2020 [27], Toll-Like Receptor 3 activator preconditioning 
was shown to be an enhancer for the modulatory function of ADMSCs in heterotopic heart transplantation. The pointed study could find that ADSCs had the highest efficiency in inhibiting lymphocyte proliferation, which was correlated with the upregulation of fibrinogenlike protein 2, leading to longer survival of cardiac allografts in transplantation.

\subsection{ADSCs and differentiation to cardiac tissue.}

The initial evidence on the pathways responsible for the differentiation of ADMSCs to heart cells was presented by Gwak et al. in 2009 by the assessment of the molecular pathways for differentiation of ADMSCs to cardiomyocytes. They focused on a specific cytokine (TGFbeta1) as a mediator the pointed cellular differentiation and could show that TGF-beta1 could induce the mRNA expression of cardiac-specific genes helping cardiac myosin heavy chain (MHC) and alpha-sarcomeric actin regeneration [28]. Thereafter, Chang et al. in 2012 [29] introduced phorbol myristate acetate, a protein kinase $\mathrm{C}$ (PKC) activator, as an important element for differentiation of ADMSCs into cardiogenic cells. Their experiment could successfully show that cardiomyocytes producing by ADMSCs in the induction of phorbol myristate acetate led to markedly reducing infarct size, interstitial fibrosis, and apoptotic index and ultimately improving cardiac functional state. Further studies could discover more mediators and pathways that induced ADSCs differentiation to cardiac tissue. As indicated by Li et al. in 2013 [30], CD73+ ADMSCs had the highest capacity among other cellular subtypes for differentiation into cardiomyocytes. Song et al. in 2013 [31] introduce Angiotensin II as a potential mediator for differentiating ADMSCs to cardiomyocyte-like cells. Zhao et al., in 2014, in another in-vitro study in 2014 [32] showed that some protein kinases enhance ADMSCs differentiation into cardiomyocytes. According to their observations, Rho-associated kinases (ROCKs) could control actin cytoskeleton reorganization, the main pathway for the production of cardiomyocytes. As an interesting result obtained by Wystrychowski et al. in 2016 [33], the affinity and potential of ADMSCs for differentiating to cardiomyocytes is significantly different in three layers of cardiac tissue. Based on their finding, epicardial ADMSCs had higher cardiomyogenic potential as compared with pericardial, and thus this finding opened up the prospect of the fact that ADMSCs derived from different adipose tissue depots may exert a diverse multi-potency in differentiating to cardiomyocytes. In order to facilitate such cellular differentiation, some authors focused their experiments on elements inducing and accelerating differentiation of ADMSCs to cardiomyocytes. In this regard, the use of 5-Azaytidine[34], Sodium valproate[35], fibrin scaffold[36] and trichostatin A [37] as the accelerators for such cellular differentiation was assessed and demonstrated through invitro experiments. However, the pathways involved in this mediating role should be further studied.

\subsection{ADMSCs and therapeutics.}

In recent years, special attention has been paid to the effectiveness of ADMSCs differentiation to cardiomyocytes or even its direct-injection, especially in combination with other therapeutics to improve cardiovascular function. In this regard, combining ADMSCs with different cardiac and even non-cardiac drugs could improve cardiac function. A primarily shown by Lin et al. in 2010 [38], combining sildenafil and ADMSCs could improve left ventricular ejection fraction along with the progression of myocardial-related angiogenesis in the background of dilated cardiomyopathy. In a similar animal study by Cai et al. in 2011 [39], 
applying ADMSCs in combination with atorvastatin as a main cardioprotective statin could be more efficient in recovering ischemic cardiac tissue following acute myocardial infarction. In an interesting experimental study by Bagno et al. in 2012 [40], administering ADMSCs directly to the myocardium could effectively improve left ventricular systolic dysfunction. Zhang et al. [41]. In 2013 could firstly describe the pathways through which statins improve cell therapeutic effects. According to their experiments, rosuvastatin could promote the therapeutic effect of ADMSCs via PI3K/Akt and MEK/ERK pathways in the sample suffering an acute myocardial infarction. Later, some studies could also reveal that the direct transplantation of ADMSCs could reduce infarct size in ischemic myocardium leading to the improvement of left ventricular functional state and [42] and ventricular dilatation remodeling [42,43]. On what mechanism is also effective in improving cardiac function after ADMSCs transformation, some studies were performed. In this regard, the inducing role of ADMSCs transformation or its direct implantation on inhibiting cardiomyocyte apoptosis, reduced fibrosis, and improved cardiac function through activation of PI3K/Akt pathway [44-47], improving tolerance to oxidative stress injury [48], mitigating cardiac damage by promoting angiogenesis and decreasing the infiltration of immune cells and collagen deposition [49], and repairing damaged myocardium by activating the SIRT1 signaling pathway (by melatonin) [50] have been discussed. In recent experimental studies, the protective role exosomes derived from ADMSCs to protect the injured myocardium against some destructive tissue pathways such as Wnt/ $\beta$-Catenin signaling pathway has also been studied. However, none of the studies focusing therapeutic effects of ADMSCs alone or in combination with other drugs have performed in the human level needing expansion of the studies at the level of clinical trials.

\section{Conclusions}

Reviewing the literature ultimately shows that directly transformation of ADMSCs to cardiomyocytes alone, embedded in platelet-rich fibrin, or along with administration of other therapeutics such as statins, melatonin, curcumin, or ghrelin can effectively improve left ventricular cardiac function by cardiac tissue regeneration. This process can be mediated by activation of some molecular pathways such as paracrine proangiogenic VEGF signaling pathway, S1P/SK1/S1PR1 signaling pathway (leading) promoting macrophage M2 polarization, phosphorylation of the Smad signaling pathway, SIRT1 signaling pathway, PI3K/Akt pathway, MEK/ERK pathway, or inactivation of some other pathways such as growth response factor 1 producing pathway and $\mathrm{Wnt} / \beta$-Catenin signaling pathway. The effects of ADMSCs as a therapeutic inducer on the pointed pathways are ultimately marked by reducing oxidative stress and inflammatory bed, reducing cardiomyocyte apoptosis, attenuating cardiac fibrosis, decreasing the infiltration of immune cells and collagen deposition, and enhancing angiogenesis that all lead to improvement of left ventricular remodeling and ejection fraction. Overall, it seems that the described in-vitro and animal studies should be evidenced by human-based studies so that its applications can be clinically productive.

\section{Funding}

This research received no external funding. 


\section{Acknowledgments}

Herby, the authors, would like to express gratitude to the Vice-Chancellor for research of Rafsanjan University of medical science.

\section{Conflicts of Interest}

The authors declare no conflict of interest.

\section{References}

1. Westphal, J.G.; Bekfani, T.; Schulze, P.C. What's new in heart failure therapy 2018? Interactive cardiovascular and thoracic surgery 2018, 27, 921-930, https://doi.org/10.1093/icvts/ivy282.

2. Machaj, F.; Dembowska, E.; Rosik, J.; Szostak, B.; Mazurek-Mochol, M.; Pawlik, A. New therapies for the treatment of heart failure: a summary of recent accomplishments. Therapeutics and clinical risk management 2019, 15, 147-155, https://dx.doi.org/10.2147\%2FTCRM.S179302.

3. Roth, G.A.; Johnson, C.; Abajobir, A.; Abd-Allah, F.; Abera, S.F.; Abyu, G.; Ahmed, M.; Aksut, B.; Alam, T.; Alam, K. Global, regional, and national burden of cardiovascular diseases for 10 causes, 1990 to 2015. Journal of the American College of Cardiology 2017, 70, 1-25, https://dx.doi.org/10.1016\%2Fj.jacc.2017.04.052.

4. González, K.; Fuentes, J.; Márquez, J.L. Physical inactivity, sedentary behavior and chronic diseases. Korean journal of family medicine 2017, 38, 111-115, https://dx.doi.org/10.4082\%2Fkjfm.2017.38.3.111.

5. Terashvili, M.; Bosnjak, Z.J. Stem cell therapies in cardiovascular disease. Journal of cardiothoracic and vascular anesthesia 2019, 33, 209-222, https://doi.org/10.1053/j.jvca.2018.04.048.

6. Banerjee, M.N.; Bolli, R.; Hare, J.M. Clinical studies of cell therapy in cardiovascular medicine: recent developments and future directions. Circulation research 2018, 123, 266-287, https://doi.org/10.1161/circresaha.118.311217.

7. Bagno, L.; Hatzistergos, K.E.; Balkan, W.; Hare, J.M. Mesenchymal stem cell-based therapy for cardiovascular disease: progress and challenges. Molecular Therapy 2018, 26, 1610-1623, https://doi.org/10.1016/j.ymthe.2018.05.009.

8. White, I.A.; Sanina, C.; Balkan, W.; Hare, J.M. Mesenchymal stem cells in cardiology. In: Mesenchymal Stem Cells. Springer: 2016; pp. 55-87, https://dx.doi.org/10.1007\%2F978-1-4939-3584-0_4.

9. Tan, S.J.O.; Floriano, J.F.; Nicastro, L.; Emanueli, C.; Catapano, F. Novel Applications of Mesenchymal Stem Cell-derived Exosomes for Myocardial Infarction Therapeutics. Biomolecules 2020, 10, https://doi.org/10.3390/biom10050707.

10. Yun, C.W.; Lee, S.H. Enhancement of functionality and therapeutic efficacy of cell-based therapy using mesenchymal stem cells for cardiovascular disease. International journal of molecular sciences 2019, 20, 982, https://doi.org/10.3390/ijms20040982.

11. Bruun, K.; Schermer, E.; Sivendra, A.; Valaik, E.; Wise, R.B.; Said, R.; Bracht, J.R. Therapeutic applications of adipose-derived stem cells in cardiovascular disease. American journal of stem cells 2018, 7, 94.

12. Miana, V.V.; González, E.A.P. Adipose tissue stem cells in regenerative medicine. Ecancermedicalscience 2018, 12, https://dx.doi.org/10.3332\%2Fecancer.2018.822.

13. Mazini, L.; Rochette, L.; Admou, B.; Amal, S.; Malka, G. Hopes and Limits of Adipose-Derived Stem Cells (ADSCs) and Mesenchymal Stem Cells (MSCs) in Wound Healing. International Journal of Molecular Sciences 2020, 21, https://dx.doi.org/10.3390\%2Fijms21041306.

14. Kilroy, G.E.; Foster, S.J.; Wu, X.; Ruiz, J.; Sherwood, S.; Heifetz, A.; Ludlow, J.W.; Stricker, D.M.; Potiny, S.; Green, P. Cytokine profile of human adipose-derived stem cells: Expression of angiogenic, hematopoietic, and pro-inflammatory factors. Journal of cellular physiology 2007, 212, 702-709, https://doi.org/10.1002/jcp.21068.

15. Weiss, A.R.R.; Dahlke, M.H. Immunomodulation by mesenchymal stem cells (MSCs): mechanisms of action of living, apoptotic, and dead MSCs. Frontiers in Immunology 2019, 10, https://doi.org/10.3389/fimmu.2019.01191.

16. Zhong, Y.C.; Wang, S.C.; Han, Y.H.; Wen, Y. Recent Advance in Source, Property, Differentiation, and Applications of Infrapatellar Fat Pad Adipose-Derived Stem Cells. Stem Cells International 2020, 2020, https://doi.org/10.1155/2020/2560174.

17. Wang, M.; Yuan, Q.; Xie, L. Mesenchymal stem cell-based immunomodulation: properties and clinical application. Stem cells international 2018, 2018, https://doi.org/10.1155/2018/3057624.

18. Senesi, L.; De Francesco, F.; Farinelli, L.; Manzotti, S.; Gagliardi, G.; Papalia, G.F.; Riccio, M.; Gigante, A. Mechanical and Enzymatic Procedures to Isolate the Stromal Vascular Fraction From Adipose Tissue: Preliminary Results. Frontiers in cell and developmental biology 2019, 7, https://dx.doi.org/10.3389\%2Ffcell.2019.00088. 
19. Gentile, P.; Calabrese, C.; De Angelis, B.; Pizzicannella, J.; Kothari, A.; Garcovich, S. Impact of the Different Preparation Methods to Obtain Human Adipose-Derived Stromal Vascular Fraction Cells (ADSVFs) and Human Adipose-Derived Mesenchymal Stem Cells (AD-MSCs): Enzymatic Digestion Versus Mechanical Centrifugation. International journal of molecular sciences 2019, 20, https://dx.doi.org/10.3390\%2Fijms20215471.

20. Malanga, G.A.; Bemanian, S. Microfragmented adipose injections in the treatment of knee osteoarthritis. Journal of Clinical Orthopaedics \& Trauma 2019, 10, 46-48, https://dx.doi.org/10.1016\%2Fj.jcot.2018.10.021.

21. Argentati, C.; Morena, F.; Bazzucchi, M.; Armentano, I.; Emiliani, C.; Martino, S. Adipose stem cell translational applications: from bench-to-bedside. International journal of molecular sciences 2018, 19, https://doi.org/10.3390/ijms19113475.

22. Orbay, H.; Tobita, M.; Mizuno, H. Mesenchymal stem cells isolated from adipose and other tissues: basic biological properties and clinical applications. Stem cells international 2012, 2012, https://doi.org/10.1155/2012/461718.

23. Colazzo, F.; Sarathchandra, P.; Smolenski, R.T.; Chester, A.H.; Tseng, Y.T.; Czernuszka, J.T.; Yacoub, M.H.; Taylor, P.M. Extracellular matrix production by adipose-derived stem cells: implications for heart

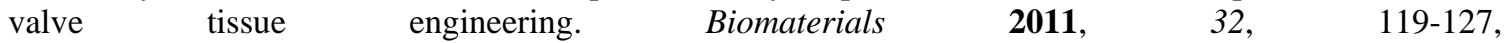
https://doi.org/10.1016/j.biomaterials.2010.09.003.

24. Morrissette-McAlmon, J.; Blazeski, A.; Somers, S.; Kostecki, G.; Tung, L.; Grayson, W.L. Adipose-derived perivascular mesenchymal stromal/stem cells promote functional vascular tissue engineering for cardiac regenerative purposes. Journal of tissue engineering and regenerative medicine 2018, 12, e962-e972, https://doi.org/10.1002/term.2418.

25. Pan, J.; Alimujiang, M.; Chen, Q.; Shi, H.; Luo, X. Exosomes derived from miR-146a-modified adiposederived stem cells attenuate acute myocardial infarction- induced myocardial damage via downregulation of early growth response factor 1. Journal of cellular biochemistry 2019, 120, 4433-4443, https://doi.org/10.1002/jcb.27731.

26. Deng, S.; Ge, Z.; Song, Y.; Wang, H.; Liu, X.; Zhang, D. Exosomes from adipose-derived mesenchymal stem cells ameliorate cardiac damage after myocardial infarction by activating S1P/SK1/S1PR1 signaling and promoting macrophage M2 polarization. The international journal of biochemistry \& cell biology 2019, 114, https://doi.org/10.1016/j.biocel.2019.105564.

27. Bao, Z.; Li, J.; Zhang, P.; Pan, Q.; Liu, B.; Zhu, J.; Jian, Q.; Jia, D.; Yi, C.; Moeller, C. Toll-Like Receptor 3 Activator Preconditioning Enhances Modulatory Function of Adipose-Derived Mesenchymal Stem Cells in a Fully MHC-Mismatched Murine Model of Heterotopic Heart Transplantation. Annals of Transplantation 2020, 25, e921287-e921287, https://dx.doi.org/10.12659\%2FAOT.921287.

28. Gwak, S.J.; Bhang, S.H.; Yang, H.S.; Kim, S.S.; Lee, D.H.; Lee, S.H.; Kim, B.S. In vitro cardiomyogenic differentiation of adipose-derived stromal cells using transforming growth factor- $\beta 1$. Cell Biochemistry and Function: Cellular biochemistry and its modulation by active agents or disease 2009, 27, 148-154, https://doi.org/10.1002/cbf.1547.

29. Chang, W.; Lim, S.; Song, B.W.; Lee, C.Y.; Park, M.S.; Chung, Y.A.; Yoon, C.; Lee, S.Y.; Ham, O.; Park, J.H. Phorbol myristate acetate differentiates human adipose-derived mesenchymal stem cells into functional cardiogenic cells. Biochemical and biophysical research communications 2012, 424, 740-746, https://doi.org/10.1016/j.bbrc.2012.07.022.

30. Li, Q.; Qi, L.J.; Guo, Z.K.; Li, H.; Zuo, H.B.; Li, N.N. CD73+ adipose-derived mesenchymal stem cells possess higher potential to differentiate into cardiomyocytes in vitro. Journal of molecular histology 2013, 44, 411-422, https://doi.org/10.1007/s10735-013-9492-9.

31. Song, K.; Wang, Z.; Li, W.; Zhang, C.; Lim, M.; Liu, T. In vitro culture, determination, and directed differentiation of adult adipose-derived stem cells towards cardiomyocyte-like cells induced by angiotensin II. Applied biochemistry and biotechnology 2013, 170, 459-470, https://doi.org/10.1007/s12010-013-02106.

32. Zhao, L.; Yang, G.; Zhao, X. Rho-associated protein kinases play an important role in the differentiation of rat adipose-derived stromal cells into cardiomyocytes in vitro. PloS one 2014, 9, https://dx.doi.org/10.1371\%2Fjournal.pone.0115191.

33. Wystrychowski, W.; Patlolla, B.; Zhuge, Y.; Neofytou, E.; Robbins, R.C.; Beygui, R.E. Multipotency and cardiomyogenic potential of human adipose-derived stem cells from epicardium, pericardium, and omentum. Stem cell research \& therapy 2016, 7, https://doi.org/10.1186/s13287-016-0343-y.

34. Bagheri-Hosseinabadi, Z.; Seyedi, F.; Mollaei, H.R.; Moshrefi, M.; Seifalian, A. Combination of 5azaytidine and hanging drop culture convert fat cell into cardiac cell. Biotechnology and Applied Biochemistry 2020, https://doi.org/10.1002/bab.1897.

35. Najafipour, H.; Bagheri-Hosseinabadi, Z.; Eslaminejad, T.; Mollaei, H.R. The effect of sodium valproate on differentiation of human adipose-derived stem cells into cardiomyocyte-like cells in two-dimensional culture and fibrin scaffold conditions. Cell and tissue research 2019, 378, 127-141, https://doi.org/10.1007/s00441019-03027-5. 
36. Bagheri-Hosseinabadi, Z.; Mesbah-Namin, S.A.; Salehinejad, P.; Seyedi, F. Fibrin scaffold could promote survival of the human adipose-derived stem cells during differentiation into cardiomyocyte-like cells. Cell and tissue research 2018, 372, 571-589, https://doi.org/10.1007/s00441-018-2799-9.

37. Bagheri-Hosseinabadi, Z.; Salehinejad, P.; Mesbah-Namin, S.A. Differentiation of human adipose-derived stem cells into cardiomyocyte-like cells in fibrin scaffold by a histone deacetylase inhibitor. Biomedical Engineering Online 2017, 16, 1-12, https://doi.org/10.1186/s12938-017-0423-y.

38. Lin, Y.C.; Leu, S.; Sun, C.K.; Yen, C.H.; Kao, Y.H.; Chang, L.T.; Tsai, T.H.; Chua, S.; Fu, M.; Ko, S.F. Early combined treatment with sildenafil and adipose-derived mesenchymal stem cells preserves heart function in rat dilated cardiomyopathy. Journal of translational medicine 2010, 8, https://doi.org/10.1186/1479-5876-8-88.

39. Cai, A.; Zheng, D.; Dong, Y.; Qiu, R.; Huang, Y.; Song, Y.; Jiang, Z.; Rao, S.; Liao, X.; Kuang, J. Efficacy of Atorvastatin combined with adipose-derived mesenchymal stem cell transplantation on cardiac function in rats with acute myocardial infarction. Acta Biochim Biophys Sin 2011, 43, 857-866, https://doi.org/10.1093/abbs/gmr087.

40. Bagno, L.L.; Werneck-de-Castro, J.P.S.; Oliveira, P.F.; Cunha-Abreu, M.S.; Rocha, N.N.; Kasai-Brunswick, T.H.; Lago, V.M.; Goldenberg, R.C.; Campos-de-Carvalho, A.C. Adipose-derived stromal cell therapy improves cardiac function after coronary occlusion in rats. Cell transplantation 2012, 21, 1985-1996, https://doi.org/10.3727/096368912x636858.

41. Zhang, Z.; Li, S.; Cui, M.; Gao, X.; Sun, D.; Qin, X.; Narsinh, K.; Li, C.; Jia, H.; Li, C. Rosuvastatin enhances the therapeutic efficacy of adipose-derived mesenchymal stem cells for myocardial infarction via PI3K/Akt and MEK/ERK pathways. Basic Research in Cardiology 2013, 108, https://doi.org/10.1007/s00395-0130333-5.

42. Preda, M.B.; Rønningen, T.; Burlacu, A.; Simionescu, M.; Moskaug, J.Ø.; Valen, G. Remote Transplantation of Mesenchymal Stem Cells Protects the Heart Against Ischemia-Reperfusion Injury. Stem Cells 2014, 32, 2123-2134, https://doi.org/10.1002/stem.1687.

43. Li, L.; Xia, Y. Study of adipose tissue-derived mesenchymal stem cells transplantation for rats with dilated cardiomyopathy. Annals of Thoracic and Cardiovascular Surgery 2014, 20, 398-406, https://doi.org/10.5761/atcs.oa.13-00104.

44. Abd Emami, B.; Mahmoudi, E.; Shokrgozar, M.A.; Dehghan, M.M.; Farzad Mohajeri, S.; Haghighipour, N.; Marjanmehr, S.H.; Molazem, M.; Amin, S.; Gholami, H. Mechanical and chemical predifferentiation of mesenchymal stem cells into cardiomyocytes and their effectiveness on acute myocardial infarction. Artificial organs 2018, 42, E114-E126, https://doi.org/10.1111/aor.13091.

45. Mori, D.; Miyagawa, S.; Yajima, S.; Saito, S.; Fukushima, S.; Ueno, T.; Toda, K.; Kawai, K.; Kurata, H.; Nishida, H. Cell spray transplantation of adipose-derived mesenchymal stem cell recovers ischemic cardiomyopathy in a porcine model. Transplantation 2018, 102, 2012-2024, https://doi.org/10.1097/tp.0000000000002385.

46. Fikry, E.M.; Hassan, W.A.; Gad, A.M. Bone marrow and adipose mesenchymal stem cells attenuate cardiac fibrosis induced by methotrexate in rats. Journal of biochemical and molecular toxicology 2017, 31, https://doi.org/10.1002/jbt.21970.

47. Han, D.; Huang, W.; Ma, S.; Chen, J.; Gao, L.; Liu, T.; Zhang, R.; Li, X.; Li, C.; Fan, M. Ghrelin improves functional survival of engrafted adipose-derived mesenchymal stem cells in ischemic heart through PI3K/Akt signaling pathway. BioMed research international 2015, 2015, https://doi.org/10.1155/2015/858349.

48. Liu, J.; Zhu, P.; Song, P.; Xiong, W.; Chen, H.; Peng, W.; Wang, S.; Li, S.; Fu, Z.; Wang, Y. Pretreatment of adipose derived stem cells with curcumin facilitates myocardial recovery via antiapoptosis and angiogenesis. Stem cells international 2015, 2015, https://doi.org/10.1155/2015/638153.

49. Ammar, H.I.; Sequiera, G.L.; Nashed, M.B.; Ammar, R.I.; Gabr, H.M.; Elsayed, H.E.; Sareen, N.; Abu-El Rub, E.; Zickri, M.B.; Dhingra, S. Comparison of adipose tissue-and bone marrow-derived mesenchymal stem cells for alleviating doxorubicin-induced cardiac dysfunction in diabetic rats. Stem cell research \& therapy 2015, 6, https://doi.org/10.1186/s13287-015-0142-X.

50. Han, D.; Huang, W.; Li, X.; Gao, L.; Su, T.; Li, X.; Ma, S.; Liu, T.; Li, C.; Chen, J. Melatonin facilitates adipose-derived mesenchymal stem cells to repair the murine infarcted heart via the SIRT1 signaling pathway. Journal of pineal research 2016, 60, 178-192, https://doi.org/10.1111/jpi.12299.

51. Zhang, Z.; Tian, H.; Yang, C.; Liu, J.; Zhang, H.; Wang, J.; Hu, S.; Sun, Z.; He, K.; Chen, G. Mesenchymal Stem Cells Promote the Resolution of Cardiac Inflammation After Ischemia Reperfusion Via Enhancing Efferocytosis of Neutrophils. Journal of the American Heart Association 2020, 9, https://doi.org/10.1161/jaha.119.014397.

52. Gao, L.; Mei, S.; Zhang, S.; Qin, Q.; Li, H.; Liao, Y.; Fan, H.; Liu, Z.; Zhu, H. Cardio-renal Exosomes in Myocardial Infarction Serum Regulate Proangiogenic Paracrine Signaling in Adipose Mesenchymal Stem Cells. Theranostics 2020, 10, 1060-1073, https://doi.org/10.7150/thno.37678.

53. Qayyum, A.A.; Mathiasen, A.B.; Mygind, N.D.; Vejlstrup, N.G.; Kastrup, J. Cardiac Magnetic Resonance Imaging used for Evaluation of Adipose-Derived Stromal Cell Therapy in Patients with Chronic Ischemic Heart Disease. Cell transplantation 2019, 28, 1700-1708, https://doi.org/10.1177/0963689719883592. 
54. Chai, H.T.; Sheu, J.J.; Chiang, J.Y.; Shao, P.L.; Wu, S.C.; Chen, Y.L.; Li, Y.C.; Sung, P.H.; Lee, F.Y.; Yip, H.K. Early administration of cold water and adipose derived mesenchymal stem cell derived exosome effectively protects the heart from ischemia-reperfusion injury. American Journal of Translational Research 2019, 11, 5375.

55. Qiao, L.; Kong, Y.; Shi, Y.; Sun, A.; Ji, R.; Huang, C.; Li, Y.; Yang, X. Synergistic effects of adiposederived stem cells combined with decellularized myocardial matrix on the treatment of myocardial infarction in rats. Life Sciences 2019, 239, https://doi.org/10.1016/j.lfs.2019.116891.

56. Sheu, J.J.; Lee, M.S.; Wallace, C.G.; Chen, K.H.; Sung, P.H.; Chua, S.; Lee, F.Y.; Chung, S.Y.; Chen, Y.L.; Li, Y.C. Therapeutic effects of adipose derived fresh stromal vascular fraction-containing stem cells versus cultured adipose derived mesenchymal stem cells on rescuing heart function in rat after acute myocardial infarction. American journal of translational research 2019, 11, 67.

57. Zhang, F.; Xie, Y.; Bian, Y. DMPE-PEG scaffold binding with TGF- $\beta 1$ receptor enhances cardiomyogenic differentiation of adipose-derived stem cells. Stem cell research \& therapy 2018, 9, https://doi.org/10.1186/s13287-018-1090-Z.

58. Cui, X.; He, Z.; Liang, Z.; Chen, Z.; Wang, H.; Zhang, J. Exosomes from adipose-derived mesenchymal stem cells protect the myocardium against ischemia/reperfusion injury through $\mathrm{Wnt} / \beta$-catenin signaling $\begin{array}{lllll}\text { pathway. Journal of } & \text { cardiovascular }\end{array}$ https://doi.org/10.1097/fjc.0000000000000507. 